\title{
Risk factors of asymptomatic bacteriuria and fetomaternal outcome following treatment in early versus late gestation
}

\author{
Muthusamy Radhamani ${ }^{1}$, Paneerselvam Amudha ${ }^{2 *}$, Balasubramanian Divya ${ }^{2}$
}

\author{
${ }^{1}$ Department of Obstetrics and Gynecology, Thanjavur Medical College, Thanjavur, Tamil Nadu, India \\ ${ }^{2}$ Department of Obstetrics and Gynecology, Government Medical College, Pudukkottai, Tamil Nadu, India
}

Received: 10 January 2022

Accepted: 24 January 2022

\section{*Correspondence:}

Dr. Paneerselvam Amudha,

E-mail: amudha70dr@gmail.com

Copyright: ( ) the author(s), publisher and licensee Medip Academy. This is an open-access article distributed under the terms of the Creative Commons Attribution Non-Commercial License, which permits unrestricted non-commercial use, distribution, and reproduction in any medium, provided the original work is properly cited.

\begin{abstract}
Background: Asymptomatic bacteriuria (ASB) has higher incidence in pregnant than in non-pregnant women and is difficult to diagnose. It is associated with fetomaternal complications like prelabour rupture of membranes, preterm labour, low birth weight and increased perinatal mortality. The aim of this study is to analyse various risk factors and the maternal and fetal outcome following treatment of asymptomatic bacteriuria in early versus late gestation.

Methods: This prospective study was conducted in Thanjavur Medical college and Hospital in 2019. The study population comprises all pregnant women attending antenatal clinic for their 1st antenatal visit.

Results: Total of 800 antenatal women were enrolled in 2 groups based on gestational age <20 weeks (n=394) and between 28 to 32 weeks $(n=406)$ at the time of their $1^{\text {st }}$ antenatal visit. Incidence of asymptomatic bacteriuria was $13.6 \%$ and $84.4 \%$ were in the age group of 21-30 years. High prevalence was noted in primigravidae (47.7\%) and in lower socioeconomic class $(70.9 \%)$. Commonest organism isolated was E. coli (42.2\%) and most of the organisms were sensitive to gentamycin $(89.9 \%)$ and cefotaxime (84.4\%). Despite treatment of asymptomatic bacteriuria, complications like anaemia, gestational hypertension \& preterm labour were higher in late detection group than in early detection group.

Conclusions: This study shows high prevalence of asymptomatic bacteriuria in pregnant women. The chances of developing maternal complications were significantly reduced after antibiotic therapy of asymptomatic bacteriuria. Hence, early screening and treatment of asymptomatic bacteriuria needs to be incorporated in routine antenatal care.
\end{abstract}

Kevwords: Asvmptomatic bacteriuria, Feto-maternal outcome, Early detection, Late detection

\section{INTRODUCTION}

Urinary tract infection is one of the most common bacterial infections encountered in clinical practice today. ${ }^{1,2}$ Nearly $50 \%$ of all women develop symptoms of urinary tract infection at some stage during their life. It is more common in pregnant than in non-pregnant women. Pregnancy is a provocative factor for asymptomatic bacteriuria (ASB) to become symptomatic. ${ }^{3}$ Symptomatic bacteriuria poses no problems because it can easily be diagnosed and treated due to its overt symptoms but asymptomatic bacteriuria is difficult to diagnose.
The presence of $>10^{5}$ bacteria $/ \mathrm{ml}$ in a single voided, clean catch midstream urine sample is satisfactory at present to define asymptomatic bacteriuria. ${ }^{4}$ The prevalence of asymptomatic bacteriuria in pregnancy ranges from 3$10 \% .^{5}$ In pregnancy, though many screening tests detect asymptomatic bacteriuria rapidly, the results are not reliable. Compared to rapid tests, quantitative urine culture was found to be the gold standard for detecting asymptomatic bacteriuria. ${ }^{6,7}$ Asymptomatic bacteriuria in pregnancy leads to low birth weight, premature rupture of membrane, preterm births and increased perinatal mortality. ${ }^{8-10}$ Treatment of asymptomatic bacteriuria in pregnancy reduces these complications and also prevents 
sequelae like pyelonephritis, acute kidney injury and chronic renal failure.

Screening and prompt management of asymptomatic bacteriuria in pregnancy has become a standard protocol in modern obstetric care in several developed countries. Considering these factors, the present study was conducted to analyse the risk factors associated with asymptomatic bacteriuria and compare the maternal and fetal outcome following treatment of asymptomatic bacteriuria in early versus late pregnancy so as to analyse the possibility of incorporating screening for asymptomatic bacteriuria in routine prenatal care.

\section{METHODS}

This prospective cohort study was conducted in the prenatal clinic of a tertiary care institution in Thanjavur in south India over a period of 1 year from January to December 2019. Institutional ethical committee approval was obtained. A total of 800 asymptomatic pregnant women of less than 20 weeks gestation $(n=394)$ and those between 28 to 32 weeks gestation $(n=406)$ who attended the prenatal clinic for the first time during the study period were enrolled. Pregnant women with symptomatic urinary tract infections, recurrent fever with chills, chronic hypertension, diabetes mellitus, sickle cell disease, history of preterm labour, gestational hypertension and fetal growth restriction in previous pregnancies were excluded from the study.

Informed consent was obtained from the study participants and their demographic details and medical history were recorded. A midstream clean catch urine sample was obtained from them and sent for culture on cystinelactose-electrolyte-deficient (CLED) agar and antibiotic sensitivity test. The culture plates were subjected to aerobic incubation at $37{ }^{\circ} \mathrm{C}$ and were interpreted after 24 hours and those which showed no growth were incubated for another 24 hours before issuing a negative report. Samples which yielded isolates with colony counts $>10^{5}$ colony forming units (cfu) per milliliter of a single uropathogen were taken as positive for ASB. Positive cultures were then tested for antibiotic susceptibility. Women diagnosed with ASB were treated with appropriate antibiotic for a week.

All women were followed up till delivery and pregnancy complications like preterm labour, gestational hypertension, anaemia, preterm labour, premature rupture of membranes and symptomatic urinary tract infections were noted. Neonatal outcome like low birth weight and neonatal sepsis were also recorded. Adverse maternal and fetal outcome were compared between the 2 groups: <20 weeks gestation (group A) and 28-32 weeks (group B).

\section{Statistical analysis}

Data are presented as rates and proportions. Statistical analysis was performed using Graph pad prism version 5 software. Fisher's exact test was used to compare the frequency between the groups. $\mathrm{p}<0.05$ was considered statistically significant.

\section{RESULTS}

A total of 800 pregnant women were enrolled in the study, out of whom 109 were positive for significant bacteriuria60 in group A (early detection) and 49 in group B (late detection). The prevalence of ASB was $13.6 \%$. Ninety two women $(84.4 \%)$ were in the age group of $21-30$ years and none under 20 years or above 35 years (Table 1). Among the culture positive women in the 2 groups, $52(47.7 \%)$ were primigravidae and $58(53.2 \%)$ were multigravidae. There was no association between ASB and parity. Majority of women with ASB (70.9\%) belonged to lower socio economic status. The demographic characteristics were comparable between the 2 groups (Table 2).

Table 1: Frequency distribution of age among pregnant women with ASB.

\begin{tabular}{|llll|}
\hline S. no & Age in years & $\mathbf{n = 1 0 9}$ & $\%$ \\
\hline $\mathbf{1}$ & $21-30$ & 92 & 84.4 \\
\hline $\mathbf{2}$ & $31-35$ & 17 & 15.6 \\
\hline
\end{tabular}

Highest prevalence of asymptomatic bacteriuria in pregnancy was in the age group of 21-30 years. The predominant isolate was $E$. coli in 46 women $(42.2 \%)$ followed by Klebsiellla in $30(27.5 \%)$ and Staphylococcus aureus in $16(14.7 \%)$ (Table 3$)$.

Antimicrobial susceptibility pattern showed that gentamicin was most effective against culture isolates in $89.9 \%$ followed by cefotaxime $(84.4 \%)$ and norfloxacin $(60.5 \%)$.

Table 2: Comparison of demographic characteristics between early and late detection groups.

\begin{tabular}{|c|c|c|c|c|c|c|c|c|}
\hline \multirow{2}{*}{$\begin{array}{l}\text { S. } \\
\text { no }\end{array}$} & \multirow[t]{2}{*}{ Parameters } & \multicolumn{2}{|c|}{$\begin{array}{l}\text { Early detection of } \\
\text { ASB } n=60\end{array}$} & \multicolumn{2}{|c|}{$\begin{array}{l}\text { Late detection of } \\
\text { ASB } n=49\end{array}$} & \multirow{2}{*}{$\begin{array}{l}\text { Chi square } \\
\text { value }\end{array}$} & \multirow[t]{2}{*}{ Df } & \multirow[t]{2}{*}{ P value } \\
\hline & & $\mathbf{N}$ & $\%$ & $\mathbf{N}$ & $\%$ & & & \\
\hline \multirow{3}{*}{1} & Age (years) & & & & & \multirow{3}{*}{3.17} & \multirow{3}{*}{1} & \multirow{3}{*}{0.074 (NS) } \\
\hline & $21-30$ & 54 & 90 & 38 & 77.5 & & & \\
\hline & $31-35$ & 6 & 10 & 11 & 22.5 & & & \\
\hline \multirow{2}{*}{2} & Gravida & & & & & \multirow{2}{*}{0.057} & \multirow{2}{*}{1} & \multirow{2}{*}{$0.81(\mathrm{NS})$} \\
\hline & Primi & 28 & 46.7 & 24 & 49 & & & \\
\hline
\end{tabular}




\begin{tabular}{|c|c|c|c|c|c|c|c|c|}
\hline \multirow{2}{*}{$\begin{array}{l}\text { S. } \\
\text { no }\end{array}$} & \multirow{2}{*}{ Parameters } & \multicolumn{2}{|c|}{$\begin{array}{l}\text { Early detection of } \\
\text { ASB } n=60\end{array}$} & \multicolumn{2}{|c|}{$\begin{array}{l}\text { Late detection of } \\
\text { ASB } n=49\end{array}$} & \multirow{2}{*}{$\begin{array}{l}\text { Chi square } \\
\text { value }\end{array}$} & \multirow[t]{2}{*}{ Df } & \multirow[t]{2}{*}{ P value } \\
\hline & & $\mathbf{N}$ & $\%$ & $\mathbf{N}$ & $\%$ & & & \\
\hline & Multi & 32 & 53.3 & 25 & 51 & & & \\
\hline \multirow{4}{*}{3} & \multicolumn{5}{|c|}{ Socio economic class } & \multirow{4}{*}{1.38} & \multirow{4}{*}{2} & \multirow{4}{*}{$0.501(\mathrm{NS})$} \\
\hline & Class III & 14 & 23.3 & 9 & 18.3 & & & \\
\hline & Class IV & 17 & 28.3 & 19 & 38.8 & & & \\
\hline & Class V & 29 & 48.3 & 21 & 42.9 & & & \\
\hline
\end{tabular}

Fisher's exact test was used to compare the frequency between the groups. NS- not significant

Table 3: Frequency distribution of type of organism isolated in urine culture in the study population.

\begin{tabular}{|llll|}
\hline S. no. & Organism & $\mathrm{n}=\mathbf{1 0 9}$ & $\%$ \\
\hline $\mathbf{1}$ & E. coli & 46 & 42.2 \\
\hline $\mathbf{3}$ & Klebsiella & 30 & 27.5 \\
\hline $\mathbf{4}$ & Staphylococcus aureus & 16 & 14.7 \\
\hline $\mathbf{5}$ & Pseudomonas & 7 & 6.4 \\
\hline $\mathbf{6}$ & Enterococcus & 4 & 3.7 \\
\hline
\end{tabular}

Table 4: Comparison of maternal and neonatal outcome between the groups based on timing of ASB detection in the study population.

\begin{tabular}{|c|c|c|c|c|c|c|c|c|c|}
\hline \multirow{2}{*}{$\begin{array}{l}\text { S. } \\
\text { no }\end{array}$} & \multirow{2}{*}{ Parameter } & \multicolumn{2}{|c|}{ Late detection (n=46) } & \multicolumn{2}{|c|}{$\begin{array}{l}\text { Early detection } \\
(\mathrm{n}=\mathbf{5 4})\end{array}$} & \multirow{2}{*}{$\begin{array}{l}\text { Chi } \\
\text { square } \\
\text { value }\end{array}$} & \multirow{2}{*}{ df } & \multirow[t]{2}{*}{$P$ value } & \multirow{2}{*}{$\begin{array}{l}\text { Relative } \\
\text { risk }\end{array}$} \\
\hline & & $\mathbf{N}$ & $\%$ & $\mathbf{N}$ & $\%$ & & & & \\
\hline \multirow{3}{*}{1} & Anemia & & & & & & & \multirow{3}{*}{$0.0019^{*}$} & \multirow{3}{*}{1.939} \\
\hline & Present & 24 & 52.1 & 12 & 22.2 & \multirow{2}{*}{9.672} & \multirow{2}{*}{1} & & \\
\hline & Absent & 22 & 47.9 & 42 & 77.8 & & & & \\
\hline \multirow{3}{*}{2} & Gestationa & erte & & & & & & & \\
\hline & Present & 10 & 21.7 & 0 & 0 & \multirow{2}{*}{13.04} & \multirow{2}{*}{1} & \multirow{2}{*}{$0.0003^{*}$} & \multirow{2}{*}{2.5} \\
\hline & Absent & 36 & 78.3 & 54 & 100 & & & & \\
\hline \multirow{3}{*}{3} & Preterm la & & & & & & & \multirow{3}{*}{$0.0013^{*}$} & \multirow{3}{*}{2.168} \\
\hline & Present & 12 & 26.1 & 2 & 3.7 & \multirow{2}{*}{10.34} & \multirow{2}{*}{1} & & \\
\hline & Absent & 34 & 73.9 & 52 & 96.3 & & & & \\
\hline \multirow{3}{*}{4} & Preterm ru & e of & ane & & & & & & \\
\hline & Present & 2 & 4.3 & 0 & 0 & \multirow{2}{*}{2.396} & \multirow{2}{*}{1} & \multirow{2}{*}{$0.121(\mathrm{NS})$} & \multirow{2}{*}{---} \\
\hline & Absent & 44 & 95.7 & 54 & 100 & & & & \\
\hline \multirow{3}{*}{5} & Prelabour & ure & orane & & & & & & \\
\hline & Present & 8 & 17.4 & 8 & 14.8 & \multirow{2}{*}{0.1227} & \multirow{2}{*}{1} & \multirow{2}{*}{$0.726(\mathrm{NS})$} & \multirow{2}{*}{---} \\
\hline & Absent & 38 & 82.6 & 46 & 85.2 & & & & \\
\hline & Low birth & & & & & & & & \\
\hline 6 & Present & 4 & 8.7 & 8 & 14.8 & & & & \\
\hline & Absent & 42 & 91.3 & 46 & 85.2 & 0.8808 & 1 & 0.348 (NS) & --- \\
\hline & Oligohydra & & & & & & & & \\
\hline 7 & Present & 2 & 4.3 & 0 & 0 & & & & \\
\hline & Absent & 44 & 95.7 & 54 & 100 & 2.396 & 1 & $0.121(\mathrm{NS})$ & ---- \\
\hline
\end{tabular}

Data are expressed as $\mathrm{n}$ with \%. Fisher's exact test was used to compare the frequencies between the groups. $*$ indicates $\mathrm{p}<0.05$ and considered statistically significant. NS- not significant. Six women were lost to follow up early detection and 3 in late detection group

Feto-maternal outcome compared between early and late detection group showed that higher proportion of women in late detection group developed anemia $(\mathrm{p}=0.0019, \mathrm{RR}$ 1.94), gestational hypertension $(\mathrm{p}=0.0003, \mathrm{RR} 2.5)$ and preterm labour $(\mathrm{p}=0.0013$, RR 2.168) than the early detection group which was statistically significant (Table 4). There was no significant difference between the 2 groups in the rates of preterm rupture of membranes $(p=0.121)$, prelabour rupture of membranes $(p=0.73)$ and oligohydramnios $(\mathrm{p}=0.121)$.

Eight (14.8\%) in early detection group and four $(8.7 \%)$ in late detection group had low birth weight babies and the 
difference was not significant $(\mathrm{p}=0.348)$. None in both groups developed pyelonephritis.

\section{DISCUSSION}

The prevalence of asymptomatic bacteriuria has been reported to be quite variable world over ranging between 2-30\%. ${ }^{11,12}$ A few Indian studies have reported a prevalence of $8-17 \%$, which was similar to the prevalence $(13.6 \%)$ found in the present study. ${ }^{10,13}$ In contrast, a few Nigerian studies have reported a very high prevalence of $45-78 \% .^{14,15}$

In our study the highest age specific prevalence of ASB was in between the age group of 21-30 years and none in $<20$ years and $>35$ years. Conversely, some authors have reported a higher prevalence of ASB in pregnant women under 20 years of age while Abdel et al had not found a statistically significant association of ASB with age..$^{10,16,17}$

In this study, we found no association between ASB and parity which was in accordance with that reported by Hazir et al and Abdel et al, while some others have reported higher rates of ASB in primigravidae..$^{10,13,16,17}$ Majority of the pregnant women with ASB in our study $(81.7 \%)$ belonged to low socio economic class and a similar observation was reported by several other studies while some found no association with socioeconomic class. ${ }^{10,11,13,17,18}$ Higher prevalence of ASB in low socio economic class can be attributed to under nutrition, poor personal hygiene and practices.

The short female urethra favours colonization by fecal flora and the pathogens associated with bacteriuria are the same in pregnant and non-pregnant women. E. coli was the commonest pathogen identified in asymptomatic bacteriuria in pregnancy. ${ }^{9-11,13,19,20}$ In the current study also, E. coli was the dominant isolate in $42.2 \%$. Klebsiella (27.5\%) and Staphylococcus aureus (14.7\%) were the other pathogens detected and most of the isolates were sensitive to gentamicin and cefotaxime. Svanborg et al state that $E$. coli strains isolated from women with asymptomatic bacteruria exhibited fewer virulence characteristics than those in women with symptomatic infection. $^{21}$

Several clinical trials have consistently reported a decrease in incidence of pyelonephrits in pregnancy following detection and treatment of ASB. ${ }^{22,23}$ But the association between ASB and pregnancy complications is uncertain and remains a topic of continued debate. ${ }^{23}$ In this study, women detected with ASB after 28 weeks of gestation and treated for it had higher incidence of preterm labour and gestational hypertension when compared to women screened and treated for ASB prior to 20 weeks of gestation. Similar observations were reported by Jain et al comparing maternal outcome in women with ASB and culture negative women between 32-34 weeks. ${ }^{20}$ Several other trials and meta-analysis also have demonstrated a significant association of ASB with preterm delivery. ${ }^{8,22,25-}$
${ }^{27}$ In contrast, Meis et al in a multiple logistic regression analysis found that bacteriuria was associated only with indicated preterm births and not with spontaneous preterm births and Kazemeir et al has reported that in uncomplicated pregnancy ASB is not associated with preterm births. ${ }^{28,29}$

A meta-analysis of 19 studies by Yan et al found 1.31 fold increased odds of preeclampsia in women with UTI.$^{30} \mathrm{It}$ was hypothesized that increased maternal inflammatory burden from UTI enhances the risk of preeclampsia. ${ }^{31}$ The same could be attributed to the higher incidence of preeclampsia (21\% versus $0 \%$ ) noted in our study among women treated for ASB late in pregnancy. Although there is adequate evidence that pyelonephritis can lead to anaemia. The association between ASB and anaemia is still not clear. Enayat et al had identified ASB as an independent risk factor for anemia. ${ }^{33}$ Higher incidence of anemia was noted in women treated for ASB after 28 weeks in our study ( $\mathrm{p}=0.0019$, RR 1.94) while it was not so in a similar study by Jain et al. ${ }^{20,32}$ The strength of association ASB with anaemia in our study should be interpreted with caution as this study did not take into account the multiple other aetiological factors of anaemia which could have confounded the results.

Even after antibiotic treatment, the women in the late detection group had higher rates of preterm rupture of membranes $(4.3 \%$ versus $0 \%)$ compared to early detection group. We found no statistical difference between the two groups in the rates of prelabour rupture of membranes, oligohydramnios or low birth weight. No women developed pyelonephritis after treatment of ASB in our study. Systematic reviews on antibiotic treatment for ASB had found only low quality evidence for a modest reduction in pyelonephritis and low birth weight infants. ${ }^{23,24}$ The clinical practice guideline issued in 2019 by the Canadian Task Force for the management of asymptomatic bacteriuria in pregnancy, recommends screening for and treating ASB. ${ }^{34}$ Though the routine screen-treat policy for ASB in pregnancy has been questioned due to lack of evidence in a study from Netherlands, further evaluation in other populations is needed to confirm if this observation could be generalized. ${ }^{29,34}$

The drawback of our study is that, the study population was not subjected to repeat screening for ASB after antibiotic therapy and recurrent asymptomatic bacteriuria could have been missed which could have influenced the outcome.

\section{CONCLUSION}

The overall prevalence of ASB in pregnancy is high, particularly in low socioeconomic class. E. coli was the commonest pathogen isolated in ASB. Asymptomatic bacteriuria detected late in pregnancy is significantly associated with maternal complications like anemia, gestational hypertension and preterm labour. Hence it is 
emphasized that routine screening and treatment of ASB should be incorporated into early prenatal care in developing countries where prevalence of ASB is high.

Funding: No funding sources

Conflict of interest: None declared

Ethical approval: The study was approved by the Institutional Ethics Committee

\section{REFERENCES}

1. Stamm WE, Norrby SR. Urinary tract infections: disease panorama and challenges. J Infect Dis. 2001;183:1-4.

2. Flores-Mireles AL, Walker JN, Caparon M, Hultgren SJ. Urinary tract infections: mechanisms of infection and treatment options. Nat Rev Microbiol. 2015;13(5):269-84.

3. Prevention of Group B Streptococcal Early Onset Disease in Newborns. ACOG committee opinion summary, Number 782. Obstet Gynecol. 2019;134(1):1.

4. Nicolle LE, Gupta K, Bradley SF, Colgan R, DeMuri GP, Drekonja D, et al. Clinical Practice Guideline for the Management of Asymptomatic Bacteriuria: 2019 Update by the Infectious Diseases Society of America. Clin Infect Dis. 2019;68(10):83-110.

5. Dwyer PL, O' Reilly M. Recurrent urinary tract infection in the female. Curr Opin Obstet Gynecol. 2002; 14(5):537-43.

6. Henderson J, Webber E, Bean S. Screening for asymptomatic bacteriuria in Adults: Updated Evidence Report and Systematic Review for the US Preventive Services Task Force. JAMA. 2019:322(12):1195-205.

7. Garingalo-Molina FD. Asymptomatic bacteriuria among pregnant women: Overview of diagnostic approaches. Phil J Microbiol Infect Dis. 2000;29:17786.

8. Mittendorf R, Williams MA, Kass EH. Prevention of preterm delivery and low birth weight associated with asymptomatic bacteriuria. Clin Infect Dis. 1992;14(4):927-32.

9. Kass EH. Pyelonephritis and bacteriuria. A major problem in preventive medicine. Ann Intern Med. 1962;56:46-53.

10. Lavanya SV, Jogalakshmi D. Asymptomatic bacteriuria in antenatal women. Indian $\mathbf{J}$ Med Microbiol. 2002;20(2):105-6.

11. Fatima N, Ishrat S. Frequency and risk factors of asymptomatic bacteriuria during pregnancy. J Coll Physicians Surg Pak. 2006;16(4):273-5.

12. Ghafari M, Baigi V, Cheragi Z, Doc Irani A. The prevalence of Asymptomatic Bacteriuria in Iranian Pregnant Women: A Systematic Review and MetaAnalysis. PLoS One. 201;11(6):e0158031.

13. Radha S, Nambisan B, Prabakaran NK, Jamal S. Prevalence and outcome of asymptomatic bacteriuria in early pregnancy. Int J Reprod Contracept Obstet Gynecol. 2017;6:223-7.
14. Imade PE, Izekor PE, Eghafona NO, Enabulele OI, Ophori E. Asymptomatic bacteriuria among pregnant women. N Am J Med Sci. 2010;2(6):263-6.

15. Amadi ES, Enemuo OB, Uneke CJ, Nwosu OK, Onyeagba RA, Ugbogu OC. Asymptomatic Bacteriuria among Pregnant Women in Abakaliki, Ebonyi State Nigeria. J Med Sci. 2007;7:698-700.

16. Hazhir S. Asymptomatic bacteriuria in pregnant women. Urol J. 2007;4(1):24-7.

17. Abdel-Aziz Elzayat M, Barnett-Vanes A, Dabour MF, Cheng F. Prevalence of undiagnosed asymptomatic bacteriuria and associated risk factors during pregnancy: a cross-sectional study at two tertiary centres in Cairo, Egypt. BMJ Open. 2017;7(3):e013198.

18. Schnarr J, Smaill F. Asymptomatic bacteriuria and symptomatic urinary tract infections in pregnancy. Eur J Clin Invest. 2008;38(2):50-7.

19. Jayalakshmi J, Jayaram VS. Evaluation of various screening tests to detect asymptomatic bacteriuria in pregnant women. Indian $\mathbf{J}$ Pathol Microbiol. 2008;51:379-81.

20. Jain V, Das V, Agarwal A, Pandey A. Asymptomatic bacteriuria \& obstetric outcome following treatment in early versus late pregnancy in north Indian women. Indian J Med Res. 2013;137(4):753-8.

21. Svanborg C, Godaly G. Bacterial virulence in urinary tract infection. Infect Dis Clin North Am. 1997;11(3):513-29.

22. Uncu Y, Uncu G, Esmer A, Bilgel N. Should asymptomatic bacteriuria be screened in pregnancy? Clin Exp Obstet Gynecol. 2002;29(4):281-5.

23. Smaill FM, Vazquez JC. Antibiotics for asymptomatic bacteriuria in pregnancy. Cochrane Database Syst Rev. 2015;(8):CD000490.

24. Moore A, Doull M, Grad R, Groulx S, Pottie K, Tonelli M, Courage S, Garcia AJ, Thombs BD; Canadian Task Force on Preventive Health Care. Recommendations on screening for asymptomatic bacteriuria in pregnancy. CMAJ. 2018;190(27):82330 .

25. Romero R, Oyarzun E, Mazor M, Sirtori M, Hobbins JC, Bracken M. Meta-analysis of the relationship between asymptomatic bacteriuria and preterm delivery/low birth weight. Obstet Gynecol. 1989;73(4):576-82.

26. Sheiner E, Mazor-Drey E, Levy A. Asymptomatic bacteriuria during pregnancy. J Matern Fetal Neonatal Med. 2009;22(5):423-7.

27. Gilstrap LC, Ramin SM. Urinary tract infections during pregnancy. Obstet Gynecol Clin North Am. 2001;28(3):581-91.

28. Meis PJ, Michielutte R, Peters TJ, Wells HB, Sands RE, Coles EC, Johns KA. Factors associated with preterm birth in Cardiff, Wales. II. Indicated and spontaneous preterm birth. Am J Obstet Gynecol. 1995;173(2):597-602.

29. Kazemier BM, Koningstein FN, Schneeberger C, Ott A, Bossuyt PM, de Miranda E, et al. Maternal and neonatal consequences of treated and untreated 
asymptomatic bacteriuria in pregnancy: A prospective cohort study with an embedded randomised controlled trial. Lancet Infect Dis. 2015;15(11):1324-33.

30. Yan L, Jin Y, Hang H, Yan B. The association between urinary tract infection during pregnancy and preeclampsia: A meta-analysis. Medicine (Baltimore). 2018;97(36):e12192.

31. Easter SR, Cantonwine DE, Zera CA, Lim KH, Parry SI, McElrath TF. Urinary tract infection during pregnancy, angiogenic factor profiles, and risk of preeclampsia. Am J Obstet Gynecol. 2016;214(3):387.

32. Hill JB, Sheffield JS, McIntire DD, Wendel GD. Acute pyelonephritis in pregnancy. Obstet Gynecol. 2005;105(1):18-23.
33. Enayat K, Fariba F, Bahram N. Asymptomatic bacteriuria among pregnant women reffered to outpatient clinics in Sanandaj, Iran. Int Barz J Urol. 2007;34:699-707.

34. Nicolle LE, Gupta K, Bradley SF, Colgan R, DeMuri PG, Drekonja D, et al. Clinical Practice Guideline for the Management of Asymptomatic Bacteriuria:2019 Update by the Infectious Diseases Society of America. Clin Infect Dis. 2019;68:83-110.

Cite this article as: Radhamani $\mathrm{M}$, Amudha $\mathrm{P}$, Divya B. Risk factors of asymptomatic bacteriuria and fetomaternal outcome following treatment in early versus late gestation. Int J Reprod Contracept Obstet Gynecol 2022;11:394-9. 